(C) 2022, The Authors. Published by Elsevier Inc. and Fass Inc. on behalf of the American Dairy Science Association ${ }^{\circledR}$. This is an open access article under the CC BY license (http://creativecommons.org/licenses/by/4.0/).

\title{
Nisin Z attenuates lipopolysaccharide-induced mastitis by inhibiting the ERK1/2 and p38 mitogen-activated protein kinase signaling pathways
}

\author{
Fuqing Huang, ${ }^{1,2} \odot$ Kunling Teng, ${ }^{1} \odot$ Yayong Liu, ${ }^{1,2} \odot$ Tianwei Wang, ${ }^{1} \odot$ Tianqi Xia, ${ }^{1,2} \odot$ Fangfei Yun, ${ }^{1,2} \odot$ \\ and Jin Zhong ${ }^{1,2 *}$ (D) \\ ${ }^{1}$ State Key Laboratory of Microbial Resources, Institute of Microbiology, Chinese Academy of Sciences, Beijing 100101, China \\ ${ }^{2}$ University of Chinese Academy of Sciences, Beijing 100049, China
}

\begin{abstract}
Nisin $\mathrm{Z}$ is a possible alternative for treating bovine mastitis by inhibiting mastitis-causing pathogens and having anti-inflammatory activity. However, the antiinflammatory mechanism of nisin $\mathrm{Z}$ on mastitis is unknown. Our study aimed to investigate the mechanisms of nisin $\mathrm{Z}$ on mastitis. Our results showed that nisin $\mathrm{Z}$ inhibited the activation of the ERK1/2 and p38 mitogen-activated protein kinase (MAPK) signaling pathway, decreased the release of pro-inflammatory cytokines (i.e., tumor necrosis factor- $\alpha$, IL-1 $\beta$, and IL-6), and increased the anti-inflammatory cytokine (IL-10) in lipopolysaccharide (LPS)-induced MCF10A cells. After intraperitoneal injection, nisin Z significantly decreased inflammatory cell infiltration in the mammary gland, as well as decreased myeloperoxidase and pro-inflammatory cytokines in serum and mammary gland. Western blot analysis revealed that nisin $\mathrm{Z}$ also dramatically suppressed the activation of the ERK1/2 and p38 MAPK signaling pathways in LPS-induced mastitis mice. We also found that nisin $\mathrm{Z}$ treatment could enhance the blood-milk barrier. In summary, our study demonstrated that nisin $\mathrm{Z}$ exerted an antiinflammatory effect by inhibiting the ERK1/2 and p38 MAPK signaling pathway and promoting the bloodmilk barrier on LPS-induced mastitis.
\end{abstract}

Key words: nisin Z, mastitis, mitogen-activated protein kinase, blood-milk barrier

\section{INTRODUCTION}

Mastitis is a common disease in humans and animals during postpartum lactation, characterized by inflammation of the mammary glands. It reduces the quality of lactation and poses a severe threat to the health of

Received October 8, 2021.

Accepted December 23, 2021

*Corresponding author: zhongj@im.ac.cn the mother and offspring (e.g., limiting the growth and development of the newborn; Larsen et al., 2010). Lipopolysaccharide is the most abundant antigen on the surface of Escherichia coli and is a typical endotoxin eliciting strong immune responses in the host ( $\mathrm{Li}$ et al., 2017; Avila-Calderón et al., 2021). Lipopolysaccharide stimulates mammary epithelial cells will activating

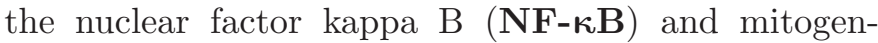
activated protein kinase (MAPK), and increasing the inflammatory mediators, and further inducing the inflammatory response (Werner-Misof et al., 2007). Found in almost all animal cell types, NF- $\kappa \mathrm{B}$ regulates multiple inflammation-related genes involved in the regulation of inflammation (Liu et al., 2017); MAPK also participates in regulating the inflammatory mediator levels (Munshi and Ramesh, 2013). The activation of each signaling pathway will result in the release of multiple cytokines, including tumor necrosis factor- $\alpha$ (TNF- $\alpha)$, IL-1 $\beta$, and IL-6, which could promote the inflammatory response (Triantafilou and Triantafilou, 2005). They act as important inflammatory cytokines and are involved in the inflammatory response of the host (Kany et al., 2019). Thus, inhibiting NF- $\kappa \mathrm{B}$ and MAPK signaling pathways is a practical approach for mastitis treatment.

As immune surveillance cells respond to external bacterial stimuli, mammary epithelial cells are the first line of defense of the mammary gland against bacterial infestation and have a protective role in the early stages of mastitis (Khan et al., 2020). Tight junctions (TJ) between the mammary epithelial cells are critical components of the blood-milk barrier, a natural barrier of mammary tissue against the invasion of pathogenic bacteria and allows only small molecules to pass through essential structures for lactation function (Kobayashi et al., 2013; Zhang et al., 2015). The TJ proteins include occludin, claudins, and linkage adhesion molecules, among which occludin and claudins have important roles in the formation of TJ (Chiba et al., 2008). However, under pathological conditions, TJ are 
damaged and cellular gaps broaden, leading to the loss of TJ and the entry of pathogenic microorganisms and pathogenic molecules into the cells. Then the bloodmilk barrier is disrupted, exacerbating the inflammatory response, thus creating a vicious cycle (Kobayashi et al., 2013, Stelwagen and Singh, 2014). Therefore, enhancing the blood-milk barrier and controlling the inflammatory response of epithelial cells is crucial to preventing mastitis.

To date, there is no reliable vaccine for mastitis, so the prevention and treatment of mastitis is a considerable challenge (Li et al., 2013). Strategies to control this disease mainly rely on antibiotics such as penicillin and cephalosporins (Kayitsinga et al., 2017; Ge et al., 2021). However, the antibiotic treatment affects animal health and reduces lactation due to high levels of leukocytes and residual antibiotics (Gillespie et al., 2002; Mehmeti et al., 2016). These have led to several food safety and health issues and have made alternative medicines urgently needed.

Nisin is a lantibiotic produced by Lactococcus lactis and is well known for its antimicrobial activity. Nisin is active against several pathogens that cause mastitis, such as Staphylococcus aureus and Streptococcus agalactiae (Broadbent et al., 1989; Wu et al., 2007). Meanwhile, nisin is also showing anti-inflammatory activity in the host. It was demonstrated that nisin was protective against the infections caused by $E$. coli through enhancing the immunity of the host individual (Kindrachuk et al., 2013). For excessive inflammation, nisin can downregulate the release of inflammatory factors and exert anti-inflammatory activity (HernándezGonzález et al., 2021). Some natural variants of nisin such as nisin $\mathrm{A}$, nisin $\mathrm{Z}$, and nisin $\mathrm{U}$ have been identified and characterized (Shin et al., 2016). Previous studies reported the effect of nisin on clinical mastitis in lactating dairy cows mainly by inhibiting mastitiscausing pathogens (Cao et al., 2007; Wu et al., 2007). However, little is known about how nisin acts for the anti-inflammatory activity to mastitis. In this study, the anti-inflammatory activity of nisin $\mathrm{Z}$ on the inflammatory model of normal mammary epithelial cells was explored, and antimastitis effects and mechanisms in mice were further investigated in LPS-induced mastitis models.

\section{MATERIALS AND METHODS}

\section{Reagents}

Nisin Z was purchased from Zhejiang Silver-Elephant Bic-engineering Co., Ltd. The LPS from E. coli was purchased from Sigma-Aldrich. Mouse and human TNF- $\alpha$, IL-1 $\beta$, IL-6, and IL-10 ELISA kits were purchased from
Bosterbio. The myeloperoxidase (MPO) assay kits were purchased from Nanjing Jiancheng Bioengineering Institute (Nanjing, China). Primary antibodies against p38, p44/42 (ERK1/2), phospho-p38 (Thr180/ Tyr182), phospho-p44/42 (ERK1/2) (Thr202/Tyr204), nuclear factor of kappa light polypeptide gene enhancer

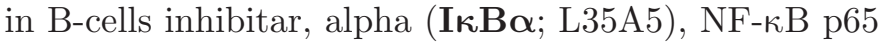


NF- $\kappa$ B p65 (Ser536) were purchased from Cell Signaling Technology. Primary antibodies against ZO-1, occludin, and claudin 3 were purchased from Bioss Co., Ltd. The HRP-conjugated Affinipure Goat Anti-Mouse IgG $\left(\mathrm{H}^{+} \mathrm{L}\right)$ was purchased from Proteintech Group, Inc.

\section{Cell Lines and Culture Condition}

Human breast epithelial cells MCF10A were purchased from Procell Life Science \& Technology Co. Ltd. The MCF10A was cultured at $37^{\circ} \mathrm{C}$ under $5 \% \mathrm{CO}_{2}$ atmosphere in DMEM/F12 with 5\% horse serum, 20 $\mathrm{ng} / \mathrm{mL}$ epidermal growth factor, $0.5 \mu \mathrm{g} / \mathrm{mL}$ hydrocortisone, $10 \mu \mathrm{g} / \mathrm{mL}$ insulin, $1 \%$ NEAA, and $1 \%$ penicillinstreptomycin. The bovine mammary epithelial cell line MAC-T was gifted by the Institute of Subtropical Agriculture, Chinese Academy of Sciences. The MAC-T was cultured in DMEM with 10\% FBS.

\section{Cell Viability Assay}

Cell Counting Kit-8 (Beyotime Biotechnology) was used to determine the cytotoxic effect of nisin $\mathrm{Z}$ on MCF10A cells. Briefly, after 3 subcultures were resuscitated, MCF10A cells were seeded into 96 well plates $\left(5 \times 10^{3}\right.$ cells/well $)$ for overnight incubation. Then $10 \mu \mathrm{L}$ of nisin $\mathrm{Z}$ solution was added to each well to give final concentrations of $200,100,50,25,12.5$, and $6.25 \mu \mathrm{g} / \mathrm{mL}$. 5-Fluorouracil $(10 \mu \mathrm{g} / \mathrm{mL})$ and the corresponding solvent concentration of DMSO were used as the positive and negative control, respectively. The supernatant was discarded and $100 \mu \mathrm{L}$ of fresh DMEM complete medium and $10 \mu \mathrm{L}$ of Cell Counting Kit- 8 solution were added and incubated for $24 \mathrm{~h}$. Then the incubation was continued for $1.5 \mathrm{~h}$ in the cell incubator and the $\mathrm{A}_{450}$ values were measured. Cell viability was calculated using the value of the negative control as a standard using the following formula: cell viability (\%) $=\left(\mathrm{A}_{\text {experimental group }} / \mathrm{A}_{\text {negative control group }}\right) \times 100 \%$. The experiment was performed in 3 independent replications.

\section{Hemolytic Activity Assay}

Sterile defibrinated sheep blood cells were used to determine the hemolytic activity of nisin Z. Briefly, sheep blood cells were washed by $1 \times$ PBS 3 times, and 
centrifuged at $400 \times g$ for $10 \mathrm{~min}$ at $4^{\circ} \mathrm{C}$. Then $0.1 \%$ SDS, $6.125,12.5,25,50,100$, and $200 \mu \mathrm{g} / \mathrm{mL}$ of nisin $\mathrm{Z}$ was added; $0.1 \%$ SDS and $1 \times$ PBS were used as the positive and negative control, respectively. The samples were incubated at $37^{\circ} \mathrm{C}$ for $1 \mathrm{~h}$, and the supernatant was centrifuged at $400 \times g$ for $10 \mathrm{~min}$ at $4^{\circ} \mathrm{C}$ to determine the $A_{540}$ values. The value of $A_{540}$ represents hemoglobin release.

\section{RNA Isolation and Quantitative Reverse- Transcription PCR}

Gene transcription levels were determined by quantitative reverse-transcription PCR (qRT-PCR). Previously published primer pairs (TNF- $\alpha$, IL-6, IL-1 $\beta$, and GAPDH; Salemi et al., 2003) and IL-10 (F: AAGCAGAGTCTCCCTTCCCT, R: GGCATCAAAAAGACCGCATTTC) for MCF10A, and primer pairs of TNF- $\alpha$ (F: GGTGGGACTCGTATGCCAAT, R: TGGTAGGAGACTGCAATGCG), IL-6 (F: CAAGCGCCTTCACTCCATTC, R: GATTTTGTCGACCATGCGCT) IL-1 $\beta$ (F: TGCCTACGCACATGTCTTCC, R: AGAGCCTTCAGCACACATGG), IL-10 (F: CTGTTGACCCAGTCTCTGCT, R: TTGCTCTTGTTTTCGCAGGG) and 18S (F: AGTGGAGCCTGCGGCTTAAT, R: CACCACCCACGGAATCGAGA) for MAC-T were synthesized by Ruibiotech (Beijing, China). The SteadyPure Universal RNA Extraction Kit, Evo M-MLV RT for PCR Kit was used to extract total RNA and reverse transcription of total RNA into cDNA, respectively. The mRNA quantification was performed using SYBR Green Premix Pro Taq HS qPCR Kit (Accurate Biology) in 96-well optical reaction plates by LightCycler 480 (Roche). The relative quantification was calculated using the $2^{-\Delta \Delta \mathrm{Ct}}$ method and mRNA quantitative data were normalized with the internal gene.

\section{Animals and Experimental Design}

The protocol for the animal experiment was approved by the Institute of Microbiology, Chinese Academy of Sciences animal ethical committee, all the ethical requirements of this study were met (approval number APIMCAS2021116). Eight-week-old female and male specific-pathogen-free Balb/c mice were purchased from the Beijing Vital River Laboratory Animal Technology Co., Ltd. Mice were housed under $22 \pm 2^{\circ} \mathrm{C}$, at about $60 \%$ humidity with $12 \mathrm{~h}$ of light and $12 \mathrm{~h}$ of darkness with a regular normal diet. After the mice had mated, and the females reproduced, the lactating mice (separated dams) were randomly divided into 6 groups by simple randomization method $(\mathrm{n}=8)$ : control group, LPS group, LPS + N1, N5, and N10 groups
(1, 5, and $10 \mathrm{mg} / \mathrm{kg}$ nisin $\mathrm{Z}$, respectively), and LPS + dexamethasone (DEX) group. The LPS $(10 \mu \mathrm{g}$ per mouse) was injected into mammary glands (L4 and R4) through the mammary duct by microsyringe with 32 $\mathrm{G}$ flat-ended needles to induce mouse mastitis under general anesthesia by intraperitoneal injecting $100 \mu \mathrm{L}$ chloral hydrate $(10 \%)$ per mouse. The mice in the nisin $\mathrm{Z}$ groups were given 1,5 , and $10 \mathrm{mg} / \mathrm{kg}$ of nisin $\mathrm{Z}$ by intraperitoneal injection $1 \mathrm{~h}$ before the nipple injection of LPS. The mice in the control group were nipple and intraperitoneal injection with $1 \times$ PBS. The blood sample was collected by retro-orbital sampling after LPS infected $24 \mathrm{~h}$. Then the mice were euthanized and the mammary gland was collected and stored at $-80^{\circ} \mathrm{C}$ for subsequent experiments.

\section{Hematoxylin and Eosin and Immunohistochemistry Staining}

Fresh mammary gland tissues were fixed in $4 \%$ paraformaldehyde for more than $24 \mathrm{~h}$. Fixed tissue of the target site was embedded in paraffin. The paraffinimpregnated tissues were embedded in the embedding machine (JB-P5, Wuhan Junjie Electronics Co.). Subsequently, approximately 5 - $\mu \mathrm{m}$-thick tissue sections were obtained by using a pathological slicer (RM2016, Shanghai Leica Instrument Co.). Further, hematoxylin and eosin or immunohistochemistry (IHC) staining was performed. Then the stained tissues were visualized under an optical microscope (Nikon Eclipse E100) and an imaging system (Nikon DS-U3).

\section{Myeloperoxidase Activity Assay}

The MPO activity was measured using the MPO assay kit. In brief, $50 \mathrm{mg}$ of mammary gland tissues were added to $1 \mathrm{~mL}$ of homogenizing medium and full ground using a glass tissue homogenizer. The homogenate and serum can be reacted with the other reagents in the assay kit according to the instructions. The enzyme activity was calculated based on absorbance at $460 \mathrm{~nm}$. Three parallel experiments were performed on each sample.

\section{Enzyme-Linked Immunosorbent Assay}

The effects of nisin $\mathrm{Z}$ on the levels of LPS-induced pro-inflammatory cytokines were determined in mammary gland tissues and MCF10A cells by ELISA. For mammary gland tissues, $50 \mathrm{mg}$ mammary gland tissues were added to $1 \mathrm{~mL}$ of tissue protein extraction reagent with protease inhibitor. The specimen well was ground with a homogenizer and centrifuged at $1,000 \times g$ for 20 min at $4^{\circ} \mathrm{C}$. The supernatant was carefully collected for 
testing. For MCF10A cells, cell culture supernatants can be used directly for testing. The serum or mammary gland tissues or MCF10A cells cytokines level of TNF- $\alpha$, IL-1 $\beta$, IL-6, and IL-10 were specifically determined by mouse or human TNF- $\alpha$, IL-1 $\beta$, IL- 6 , and IL-10 ELISA kits, respectively.

\section{Western Blotting}

Total protein from mouse mammary tissue and MCF10A cells was extracted using RIPA lysis buffer (Huaxingbio) according to instructions. Total protein concentration was determined using the Pierce BCA Protein Assay Kit (Thermo Scientific). Equal amounts of protein from each group were subjected to 4 to $20 \%$ SDS polyacrylamide gels and transferred onto formaldehyde-activated polyvinylidene difluoride membranes. Followed by overnight blocking with $5 \%$ skim milk at $4^{\circ} \mathrm{C}$, the membranes were incubated with primary antibodies $(1: 1,000)$ for $2 \mathrm{~h}$, following HRP-conjugated Affinipure Goat Anti-Mouse $\operatorname{IgG}\left(\mathrm{H}^{+} \mathrm{L} ; 1: 5,000\right)$ for 1 $\mathrm{h}$ at room temperature. Enhanced chemiluminescence reagent was used for displaying and imaging on a chemiluminescence imaging system; GAPDH was used as an internal reference antibody.

\section{Statistical Analyses}

All data are presented as the mean \pm standard error of the mean in our study, and data were analyzed and imaged with Graphpad Prism 7.0 software (Prism). The differences between the groups were evaluated using one-way ANOVA and Student's t-test. The significance was defined at $P<0.05$.

\section{RESULTS}

\section{Safety Assessment of Nisin Z}

The potential cytotoxicity and hemolytic activity of nisin Z on MCF10A cells were analyzed. When treated with nisin $\mathrm{Z}$ lower than $200 \mu \mathrm{g} / \mathrm{mL}$, the cell viability of MCF10A was not significantly different from that of the control group (Figure 1A). Meanwhile, nisin Z treatment resulted in no release of hemoglobin at a concentration lower than $200 \mu \mathrm{g} / \mathrm{mL}$ (Figure 1B). These results showed that the application of nisin $\mathrm{Z}$ should be considered secure.

\section{Effect of Nisin Z on LPS-Induced Inflammatory Response In Vitro}

To check whether nisin Z has anti-inflammatory activity in vitro, the MCF10A cells were induced by LPS, and the effects of nisin $\mathrm{Z}$ on transcription and translation levels of cytokines in MCF10A cells were analyzed by qPCR and ELISA, respectively. The results showed that LPS significantly increased $(P<0.001)$ the transcript levels of $\operatorname{tnf}-\alpha, i l-6$, and $i l-1 \beta$. Nisin $\mathrm{Z}$ at 50 and $100 \mu \mathrm{g} / \mathrm{mL}$ significantly downregulated $(P<0.01)$ the
A

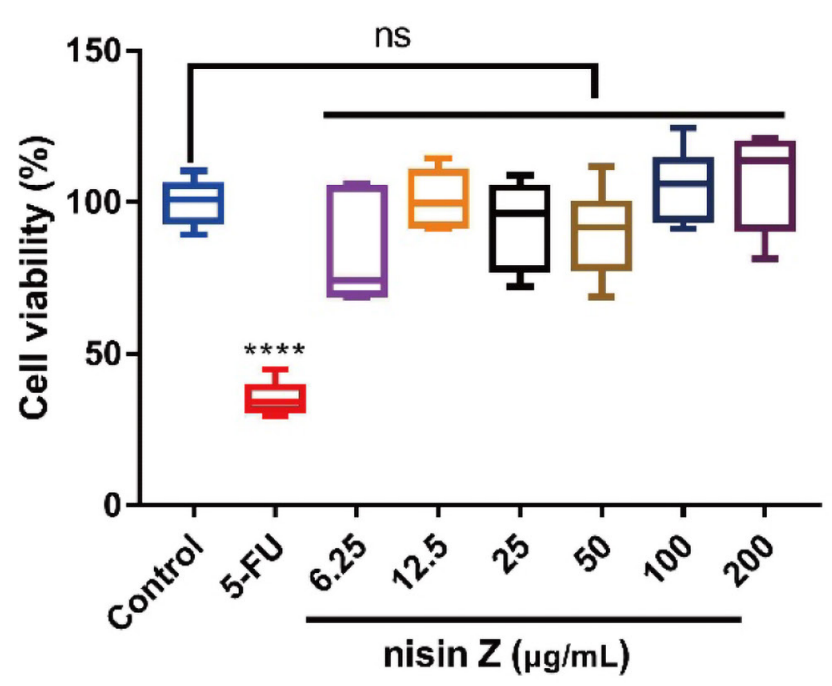

B

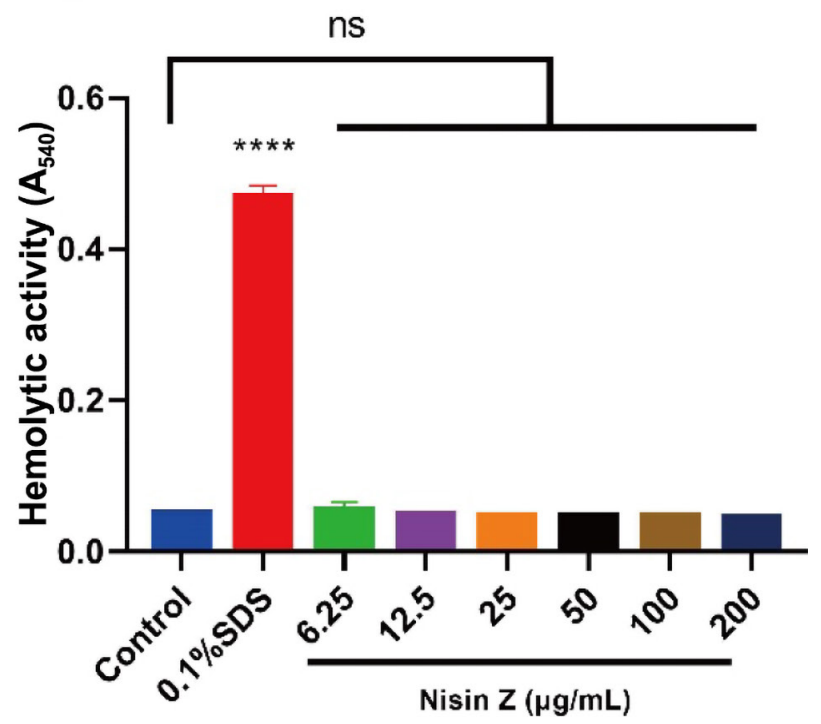

Figure 1. Safety assessment of nisin Z. (A) Cell viability of MCF10A cells after $12 \mathrm{~h}$ of nisin Z treatment $(6.25-200 \mu \mathrm{g} / \mathrm{mL})$. (B) The hemolytic activity of nisin $\mathrm{Z}$ and the value of $\mathrm{A}_{540}$ represent hemoglobin release. Values are presented as mean $\pm \mathrm{SEM}(\mathrm{n}=3)$. $* * * * P<0.0001$ versus control. $\mathrm{ns}=$ no statistical significance. 5 -FU $=5$-fluorouracil. 
transcript levels of these genes in a dose-dependent manner (Figure 2A-C). For the translation levels, LPS significantly increased $(P<0.0001)$ IL-6, TNF- $\alpha$, and IL-1 $\beta$ content in the supernatant of MCF10A cells. The intervention of nisin Z significantly reduced the IL-6 $(P<0.05)$ level in a dose-dependent manner, and significantly decreased the TNF- $\alpha$ and IL-1 $\beta$ levels at 100 $\mu \mathrm{g} / \mathrm{mL}(P<0.001 ;$ Figure $2 \mathrm{E}-\mathrm{G})$. The level of IL-10 was significantly increased in response to LPS stimulation. A further significant increase with dose-dependent in IL-10 levels was observed with simultaneous treatment with nisin $\mathrm{Z}$ (Figure 2D and $2 \mathrm{H}$ ). In addition, we also checked the effect of nisin $\mathrm{Z}$ on bovine mammary epithelial cells MAC-T, and the results (Figure 2I-L) were consistent with those of MCF10A cells. These results suggested that nisin $\mathrm{Z}$ can reduce the production of LPS-induced pro-inflammatory cytokines (i.e., IL-6, TNF- $\alpha$, IL-1 $\beta$ ), and increase the anti-inflammatory cytokines (i.e., IL-10), thus exerting anti-inflammatory effects.

\section{Effect of Nisin Z on NF-KB/MAPK Signaling Pathways of LPS-Induced Inflammatory Response on MCF10A Cells}

The LPS-induced inflammatory responses are usually associated with the activation of inflammatory signaling pathways. To determine whether nisin $\mathrm{Z}$ has an effect on NF- $\kappa \mathrm{B}$ or MAPK signaling pathways, the expression of related proteins was examined by western blotting (WB). The results showed that LPS stimulation induced the increasing phosphorylation of p65 and $\mathrm{I} \kappa \mathrm{B} \alpha(P<0.01)$ in the NF- $\kappa \mathrm{B}$ signal pathway compared with the control group. The results of p38 $(P<$ $0.0001)$ and ERK1/2 $(P<0.0001)$ in the MAPK signal pathway were similar (Figure 3 ). In contrast, nisin Z significantly inhibited the phosphorylation of p38 $(P<$ $0.01)$ and ERK1/2 $(P<0.0001)$ in the MAPK signal pathway in a dose-dependent manner compared with the LPS group (Figure 3D-F). However, there was no significant decrease of the p65 and I $\kappa \mathrm{B} \alpha$ phosphorylation levels compared with the LPS group (Figure $3 \mathrm{~A}-\mathrm{C})$. Our results indicated that nisin $\mathrm{Z}$ could inhibit the LPS-induced inflammatory response in MCF10A cells by inhibiting the activation of the MAPK signaling pathway.

\section{Effect of Nisin Z on Mammary Histopathological Changes in LPS-Induced Mice Mastitis}

To further investigate the in vivo anti-inflammatory activity of nisin Z, a mastitis mouse model was con- structed. Mastitis was caused by LPS and was treated with nisin Z, DEX, or PBS one hour before treatment of LPS. The mastitis mice with DEX intervention were used as a positive control (DEX group), and the mice without LPS and any drug treatment as a negative control (control group; Figure 4A). There was no significant change in the mouse $\mathrm{BW}$ in each group of the mastitis mice compared with both controls (Figure 4B). The results of histopathological changes showed no visible tissue damage or inflammatory cell infiltration in the negative control group (Figure 4C). Infiltration of inflammatory cells was evident in the acini of the positive control group, and some acini have shrunk. However, in the nisin Z- and DEX-treated groups, inflammatory cell infiltration was reduced and the acini was not destroyed. Our result demonstrated that nisin Z (1, 5, and $10 \mathrm{mg} / \mathrm{kg})$ and DEX $(5 \mathrm{mg} / \mathrm{kg})$ treatment prevented the pathological damage caused by LPS.

\section{Effects of Nisin Z on MPO Activity and Proinflammatory Cytokines Content of Mastitis Mice}

Myeloperoxidase is massively expressed in neutrophils, and MPO activity in mammary gland tissue is a signature of inflammatory cell infiltration. Our results showed that the MPO activity of serum and the mammary gland was significantly increased in the LPS group $(P<0.0001)$. However, injection of nisin $\mathrm{Z}$ decreased the activity of serum $(P<0.05$ at LPS $+\mathrm{N} 5, P<0.01$ at LPS + N10) and mammary gland $(P<0.01$ at LPS $+\mathrm{N} 5, P<0.0001$ at LPS + N10 $)$ $\mathrm{MPO}$ in a dose-dependent manner (Figure $5 \mathrm{~A}$ and $5 \mathrm{~B})$. The ELISA results showed that TNF- $\alpha$, IL-6, and IL-1 $\beta$ contents were significantly increased in the LPS group $(P<0.0001)$. In contrast, when compared with the LPS group, the serum TNF- $\alpha$ in the LPS $+\mathrm{N} 5(P<0.001)$, LPS $+\mathrm{N} 10(P<0.01)$ groups (Figure 5C), and the serum IL-6 in the LPS+N1, LPS $+\mathrm{N} 5$, and LPS + N10 groups were significantly decreased (Figure 5D; $P<0.0001$ ), compared with the LPS group. Similar results were obtained for IL-1 $\beta$ (Figure 5E). The mammary gland IL-6 in the LPS + N5, LPS + N10 groups $(P<0.0001)$, and IL-1 $\beta$ in the LPS $+\mathrm{N} 10$ group $(P<0.05)$ were significantly decreased compared with the LPS group (Figure 5G and $5 \mathrm{H}$ ). These results suggested that nisin $\mathrm{Z}$ injections alleviate LPS-induced mastitis in mice by facilitating the reduction of inflammatory signatures and inflammatory cytokine levels. 
Effect of Nisin Z on the MAPK Signaling Pathway in LPS-Induced Mice Mastitis

Based on our results that nisin Z inhibits LPS-induced activation of the MAPK signaling pathway in MCF10A cells, we would like to know whether nisin $\mathrm{Z}$ exerts an inhibitory effect on mastitis by inhibiting the MAPK signaling pathway in mice. We investigated the expression levels of p38, p-p38, ERK1/2, and p-ERK1/2 by WB in mice treated with LPS and nisin $\mathrm{Z}$ as mentioned $\square$ Control

$\square$ LPS $+20 \mu \mathrm{g} / \mathrm{mL}$ nisin $\square$ LPS

$\square$ LPS $+50 \mu \mathrm{g} / \mathrm{mL}$ nisin
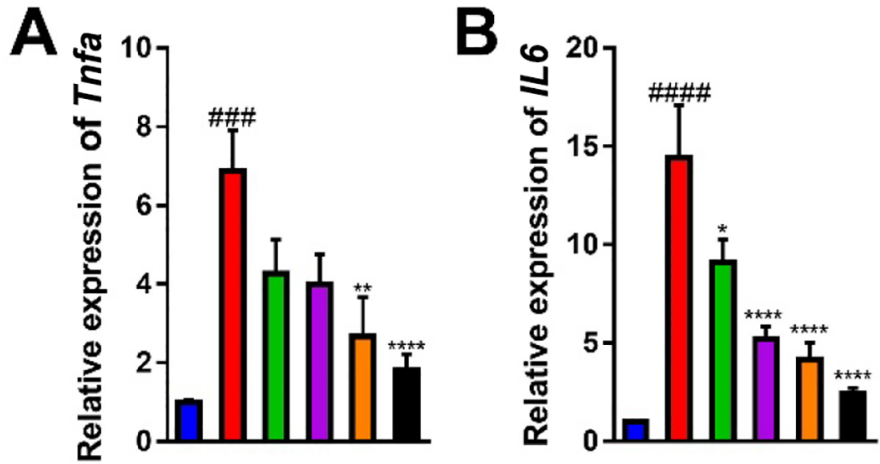

C

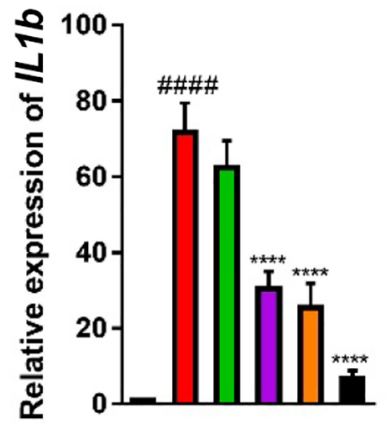

LPS $+10 \mu \mathrm{g} / \mathrm{mL}$ nisin

LPS $+100 \mu \mathrm{g} / \mathrm{mL}$ nisin
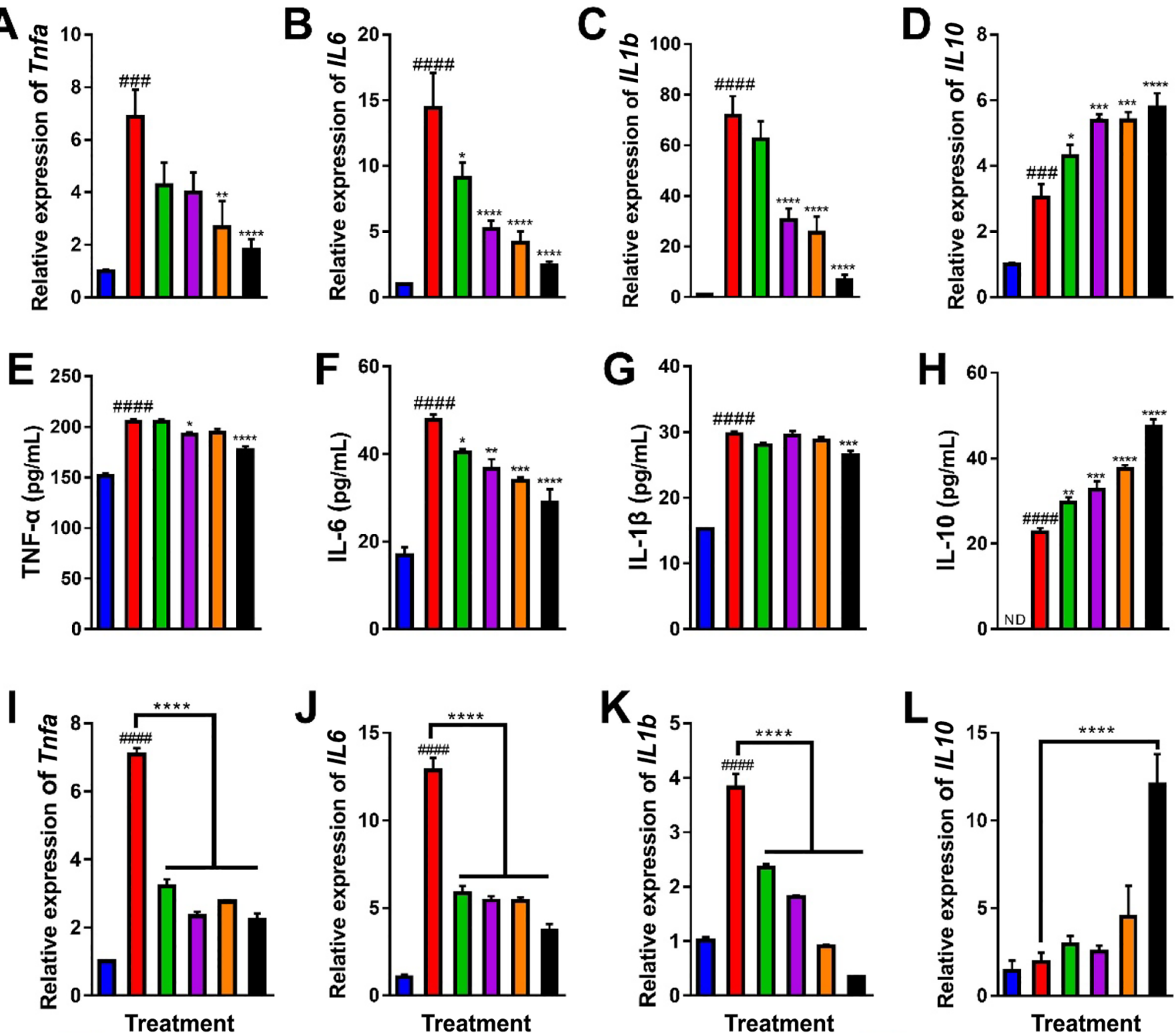

Figure 2. Effect of nisin $\mathrm{Z}$ on the LPS-induced proinflammatory cytokines in vitro. The transcription levels of proinflammatory cytokine genes of Tnfa, il-6, Il1b, and $\operatorname{ll} 10$ in MCF10A (A, B, C, and D) and MAC-T (I, J, K, and L) cell lines were detected by quantitative reversetranscription PCR. The protein levels of proinflammatory cytokines of TNF- $\alpha$, IL-6 IL-1 $\beta$, and IL-10 (E, F, G, and H) were detected by ELISA. Values are presented as mean \pm SEM $(\mathrm{n}=3)$. ${ }^{*} P<0.05,{ }^{* *} P<0.01,{ }^{* * *} P<0.001,{ }^{* * * *} P<0.0001$ versus LPS group. ${ }^{\# \# \# \# ~} P<0.0001$ versus control group. 
above. Our results demonstrated that the phosphorylation levels of p38 $(P<0.0001)$ and ERK1/2 $(P<0.05)$ proteins were significantly increased in the LPS group. However, the phosphorylation levels of p38 protein in the LPS $+\mathrm{N} 1, \mathrm{LPS}+\mathrm{N} 5$, and $\mathrm{LPS}+\mathrm{N} 10$ groups $(P<$ $0.0001)$, and ERK1/2 protein in the LPS $+\mathrm{N} 10$ group $(P<0.05)$ were significantly decreased compared with the LPS group (Figure 6). These results demonstrated that nisin $\mathrm{Z}$ might prevent LPS-induced mastitis in mice by blocking the activation of the ERK1/2 and p38 MAPK signaling pathways.

\section{Effect of Nisin Z on the Integrity of Blood-Milk Barrier in LPS-Induced Mice Mastitis}

To assess whether nisin $\mathrm{Z}$ affected the blood-milk barrier, the expression of TJ proteins such as claudin 3, occludin, and ZO-1 were determined by IHC and WB analysis. In our study, LPS did not lead to a significant decrease in TJ protein expression from the results of IHC results. However, a parallel intervention with nisin on the base of LPS would have a further facilitative effect on the expression of TJ proteins (Figure 7A-C). The LPS + N5 and LPS + N10 groups significantly increased the expression of occludin and ZO-1 compared with the LPS group from the WB analysis, which supports the IHC results (Figure 7D-G). These results indicated that nisin $\mathrm{Z}$ might prevent LPS-induced mastitis in mice via enhancing the blood-milk barrier.

\section{DISCUSSION}

Mastitis is an inflammatory disease of the mammary gland closely related to the release of inflammatory mediators and usually caused by pathogenic microbial infections (Burvenich et al., 2003; Ingman et al., 2014). Nisin has powerful bactericidal and antibacterial activity against many mastitis-related pathogenic bacteria to inhibit mastitis (Cao et al., 2007; Wu et al., 2007). However, there is insufficient research in the antiinflammatory activity and the detailed mechanism of nisin in mastitis. Here we showed that nisin $\mathrm{Z}$ inhibited
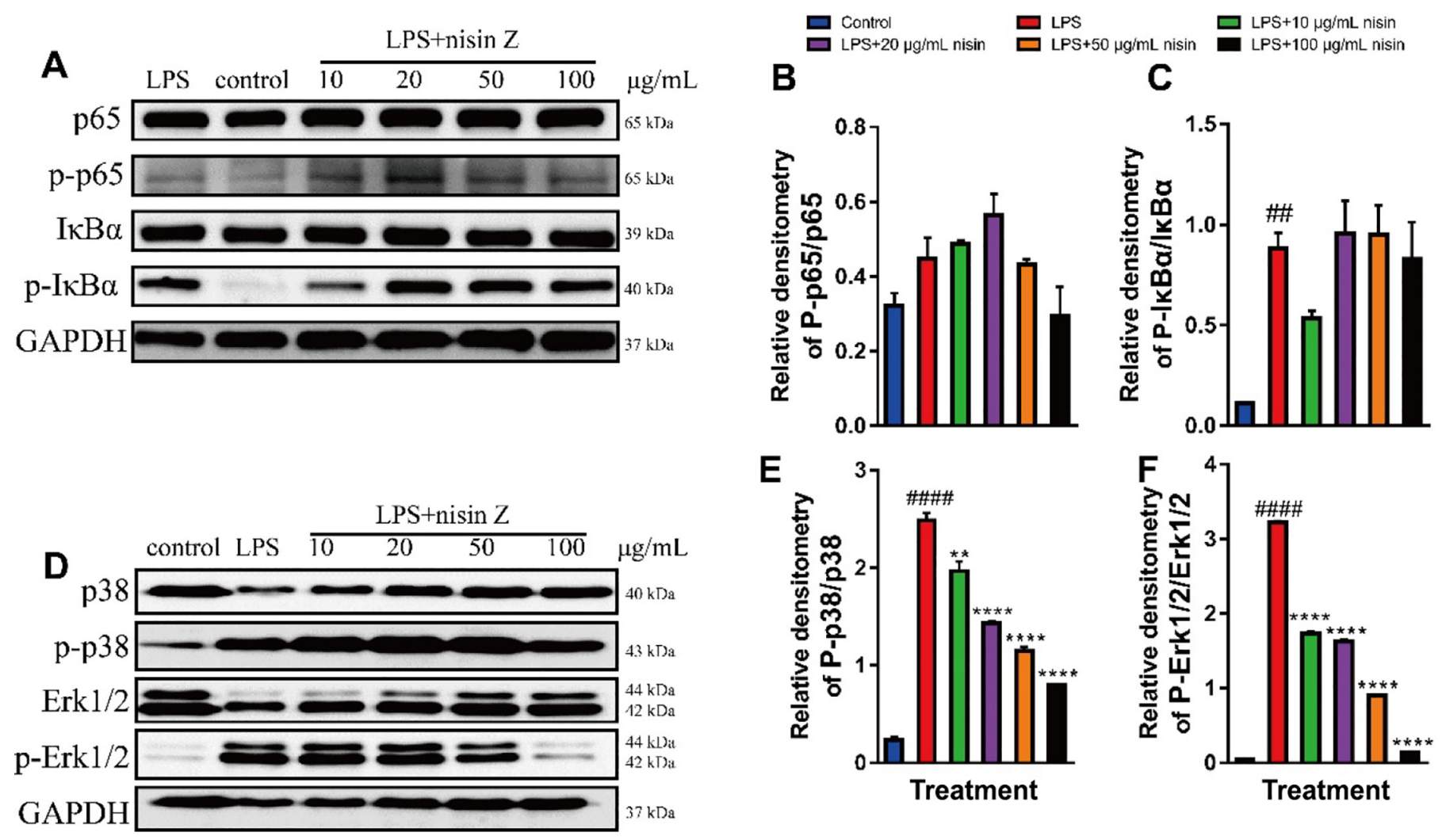

Figure 3. Effect of nisin $\mathrm{Z}$ on expression of proteins related to inflammatory response in MCF10A cells. (A) Protein bands of p65, phosphory-



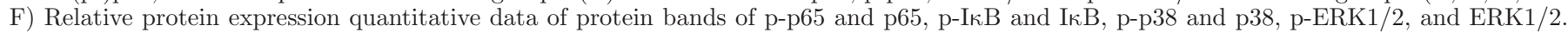
All protein expression quantitative data were first normalized by GAPDH, and then the relative quantification of phosphorylated and nonphosphorylated proteins was performed $(\mathrm{n}=2)$. ${ }^{* *} P<0.01$, ${ }^{* * * *} P<0.0001$ versus LPS group. ${ }^{\# \#} P<0.01$, \#\#\#\# $P<0.0001$ versus control group. 
inflammation response in vitro and in LPS-induced mastitis mice and further explored the potential mechanism.

Guaranteeing security is a fundamental prerequisite for using drugs to intervene in diseases. We have demonstrated that nisin Z has a nontoxic effect on MCF10A cells, which is consistent with the previous report that nisin $\mathrm{Z}$ was not toxic to human keratinocyte cell line (HaCaT) cells at concentrations below $200 \mu M$ (about $700 \mu \mathrm{g} / \mathrm{mL}$; Lewies et al., 2018). Below $750 \mu \mathrm{M}$, nisin has no hemolytic activity (Begde et al., 2011), and similar results were obtained in our study. Hence, the dose of nisin $\mathrm{Z}$ used in this study can be considered secure.
Cytokine production is critical in developing inflammation (Turner et al., 2014). Pro-inflammatory cytokines induce the development of inflammation tends to result in an inflammatory response that exceeds the normal protection requirement of the organism and produces over-excited inflammation (Chen et al., 2017). Anti-inflammatory cytokines have a regulatory effect on the inflammatory response. Our results showed that nisin Z can inhibit LPS-induced overproduction of proinflammatory cytokines IL-6, IL- $1 \beta$, and TNF- $\alpha$, and increase the level of anti-inflammatory cytokine IL-10 in vitro. This indicates nisin $\mathrm{Z}$ has a strong anti-inflammatory activity in vitro. It is reported that nisin A also showed anti-inflammatory activity and significantly

A

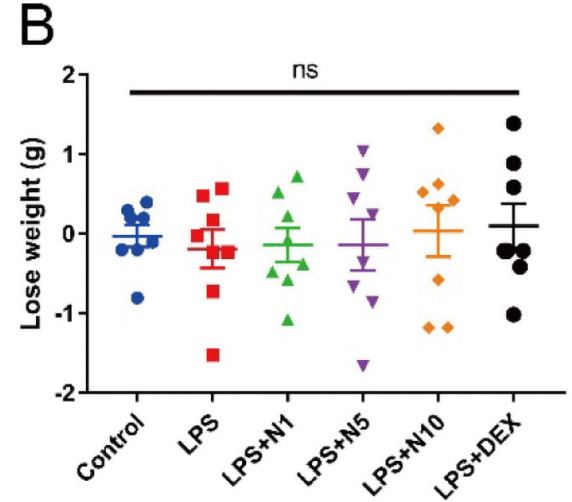

C

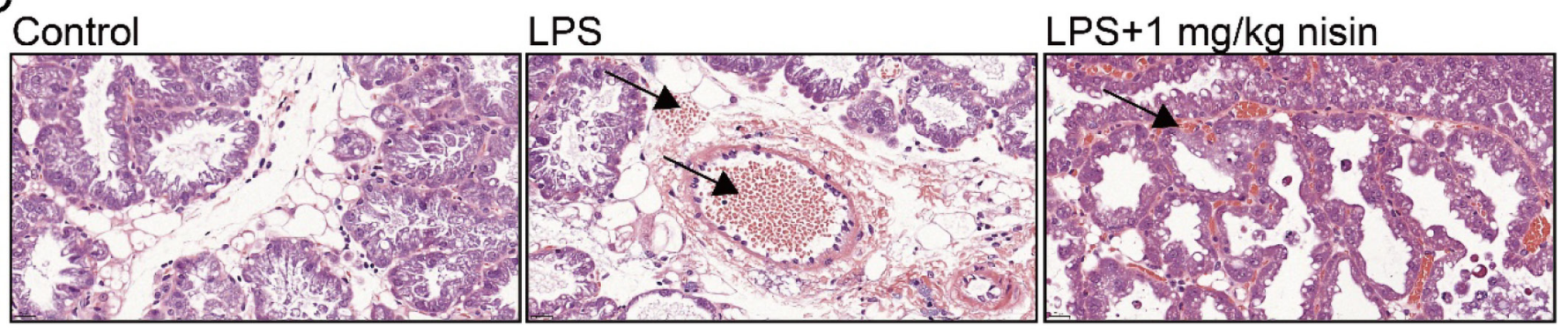

LPS+5 mg/kg nisin

LPS+10 mg/kg nisin

LPS $+5 \mathrm{mg} / \mathrm{kg}$ DEX
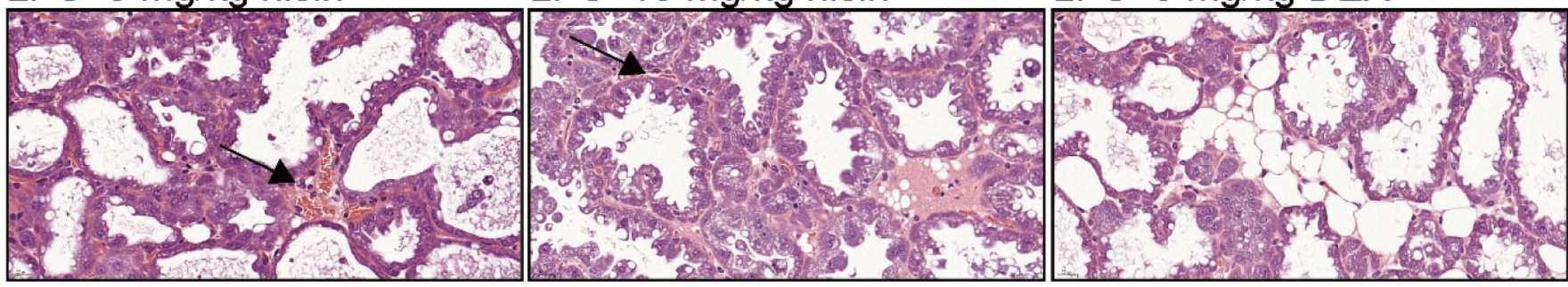

$100 \mu \mathrm{m}$

Figure 4. Effect of nisin $\mathrm{Z}$ on mammary histopathological changes in LPS-induced mice mastitis. (A) Flowchart of the mouse experiment. (B) Lose weight in mice at $25 \mathrm{~h}$ after nisin $\mathrm{Z}$ and dexamethasone (DEX) treatment $(\mathrm{n}=8)$. (C) Histopathological changes in mammary gland tissues of different groups of mice $(\mathrm{n}=3) . \mathrm{ns}=$ no statistical significance. LPS groups: LPS $+\mathrm{N} 1, \mathrm{~N} 5$, and N10 groups $(1,5$, and 10 mg/kg of nisin Z, respectively). 
A

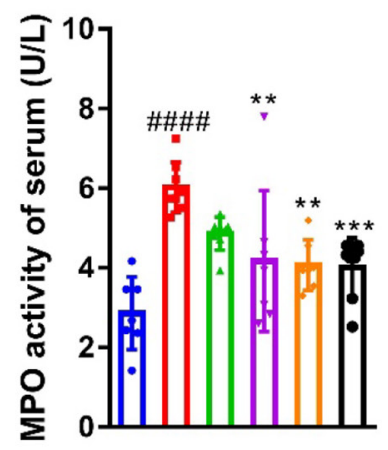

B

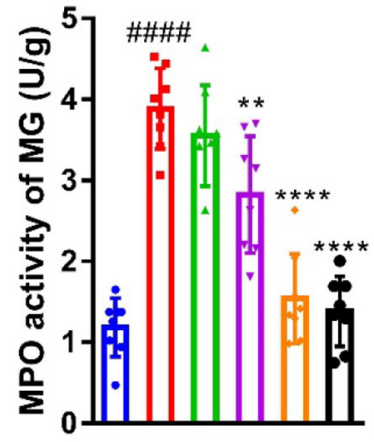

- Control

- LPS

- LPS+N1

- LPS+N5

- LPS+N10

- LPS+DEX
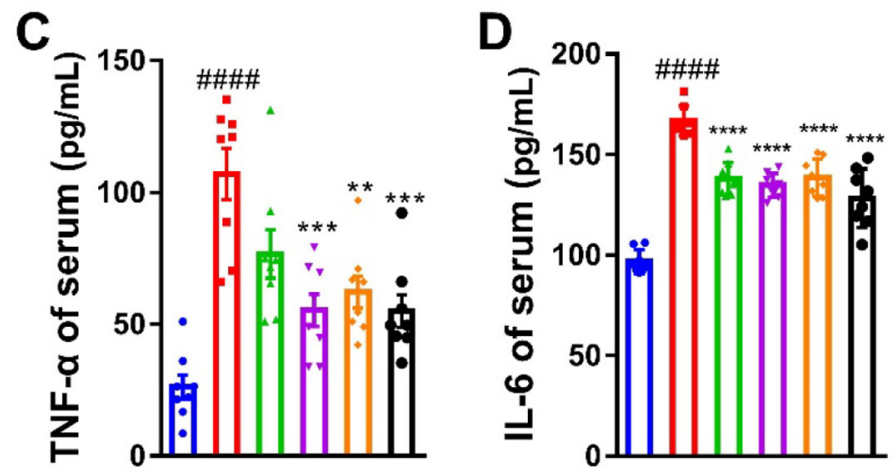

E
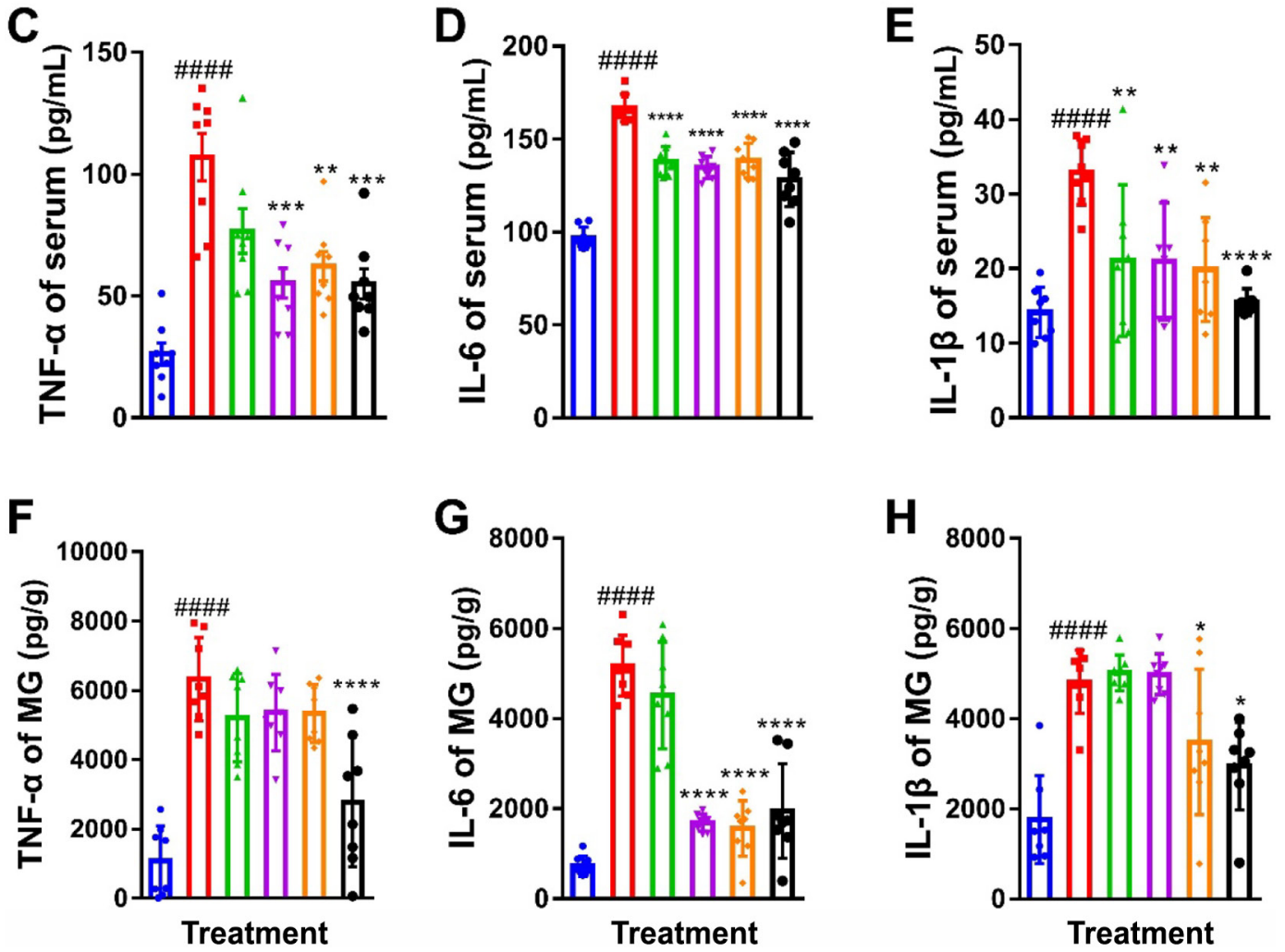

Figure 5. Effects of nisin $\mathrm{Z}$ on the myeloperoxidase (MPO) activity and the levels of proinflammatory cytokines in serum and mammary

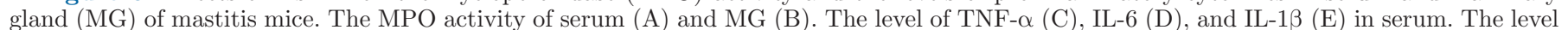
of TNF- $\alpha(\mathrm{F})$, IL-6 (G), and IL-1 $\beta(\mathrm{H})$ in MG. Values are presented as mean \pm SEM $(\mathrm{n}=8) .{ }^{*} P<0.05,{ }^{* *} P<0.01,{ }^{* * *} P<0.001,{ }^{* * * *} P<$ 0.0001 versus LPS group. ${ }^{\# \# \# ~} P<0.0001$ versus control group.

reduced pro-inflammatory cytokines TNF- $\alpha$ and IL-6 levels in LPS-induced HaCaT cells (Mouritzen et al., 2019). This report supports our conclusion that nisin Z has anti-inflammatory activity by reducing the expression of proinflammatory cytokines. In our study, the differences in mRNA expression are more significant than those in cytokine secretion. However, they showed overall similar trends in mRNA and cytokines secretion. In this sense, nisin $\mathrm{Z}$ exerts an anti-inflammatory response. A similar phenomenon is also reported by Akhtar et al. (2020).

Studies have demonstrated that E. coli (Zheng et al., 2021) or LPS (Kan et al., 2019) could induce lesions in the mouse mammary gland tissue, increasing the levels of TNF- $\alpha$, IL-6, and IL-1 $\beta$. These inflammatory indices were significantly downregulated after intervention with anti-inflammatory substances, alleviating LPSinduced inflammation. In our study, nisin Z inhibited 


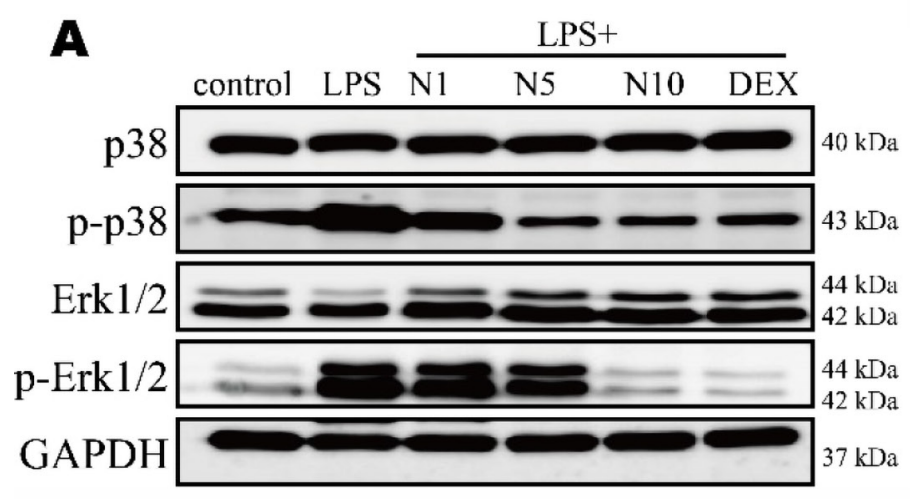

Figure 6. Effect of nisin Z on the MAPK signaling pathway in LPS-induced mice mastitis. (A) Protein bands of p38, phosphorylated (p)p38, ERK1/2, and p-ERK1/2 in different groups. Relative protein expression quantitative data of protein bands of p-p38 and p38 (B) and p-ERK1 $/ 2$ and ERK1/2 (C). All protein expression quantitative data were first normalized by GAPDH, and then the relative quantification of phosphorylated and nonphosphorylated proteins was performed $(\mathrm{n}=2) .{ }^{*} P<0.05,{ }^{* * * *} P<0.0001$ versus LPS group. ${ }^{\#} P<0.05,{ }^{\# \# \# \#} P<$ 0.0001 versus control group.

the LPS-induced elevation of IL-6, IL-1 $\beta$, and TNF- $\alpha$ of serum and mammary gland, and mastitis reduction was dose-dependent with nisin $\mathrm{Z}$ in mice. This result is consistent with our result in vitro (Figure 2). This was also supported by the report demonstrating that


and $T N F-\alpha$ ) in rats with endometritis, alleviating the inflammation (Jia et al., 2019). Similarly, myricetin inhibited the levels of mammary gland IL-6, IL-1 TNF- $\alpha$ caused by LPS in mastitis mice (Kan et al., 2019). Thus, nisin $\mathrm{Z}$ reduced proinflammation cytokines both in mammary gland cell lines and animal models.

Our result of histopathological changes in the mammary gland suggested that nisin $\mathrm{Z}$ significantly inhibited inflammatory cell infiltration and reversed structural damage to the mammary gland. Myeloperoxidase is an enzyme found primarily in the neutrophil primordial granules and is a biomarker of neutrophil influx into the tissue (Khan et al., 2018). Allicin can inhibit the MPO activity of mastitis mice (Chen et al., 2019), which is consistent with our result that nisin Z significantly inhibited the increased MPO activity. The reduction of MPO activity also supports the result of histopathological changes.

The protein complex NF- $\kappa \mathrm{B}$ is a critical component of the inflammatory response. In the unstimulated state, the NF- $\kappa \mathrm{B}$ p65 subunit is shielded from translocation to the nucleus by binding to the repressor protein $\mathrm{I} \kappa \mathrm{B} \alpha$, which blocks its nucleus localization signal. Inflammatory stress leads to phosphorylation and degradation of $\mathrm{I} \kappa \mathrm{B} \alpha$, releasing $\mathrm{NF}-\kappa \mathrm{B}$ p65 subunits into the nucleus and promoting transcription of genes related to inflammatory (Zeng et al., 2020). Therefore, inhibiting
NF- $\kappa \mathrm{B}$ signaling has potential therapeutic applications in inflammatory diseases (Dilshara et al., 2014). We have investigated the activation of the NF- $\kappa \mathrm{B}$ signaling pathway in MCF10A cells. However, we detected an increase in the phosphorylation level of NF- $\kappa \mathrm{B}$ p65 and $\mathrm{I} \kappa \mathrm{B} \alpha$ treated with LPS, whereas no inhibition of phosphorylation was observed after nisin $\mathrm{Z}$ treatment. We supposed that nisin Z inhibits proinflammatory cytokines in mastitis mice not by inhibiting the NF- $\kappa B$ pathway, which is different from the mechanism of certain anti-mastitis substances, such as myricetin (Kan et al., 2019), nuciferine (Chen et al., 2018), and astragalin (Li et al., 2013). Another critical signaling pathway associated with inflammation is MAPK, and the activation of this pathway will trigger the release of massive pro-inflammatory mediators. It has been shown that the inhibition of the MAPK signaling pathway could effectively reduce the inflammation of bovine mammary epithelial cells (Wang et al., 2016). We demonstrated that nisin $\mathrm{Z}$ decreased the phosphorylation of p38 and ERK1/2 in LPS-stimulated MCF10A cells and mastitis mice. This result indicates that nisin might inhibit proinflammatory cytokines might through inhibiting the MAPK signaling pathway. A similar mechanism is also found for vanillin (Guo et al., 2019), cynatratoside-C (Hu et al., 2018), and gambogic acid (Tang et al., 2020), which also alleviate LPS-induced mastitis in mice by inhibiting MAPK. Kindrachuk et al. (2013) also reported nisin Z decreased the content of IL-6 and inhibited the ERK/MAPK in murine splenocytes. In our study, LPS induced high levels of IL- $1 \beta$ and TNF- $\alpha$, which are reported to induce NF- $\kappa \mathrm{B}$ activation. Nisin $\mathrm{Z}$ treatment reduced the levels of IL-1 $\beta$ and TNF- $\alpha$ secretion only to 
A

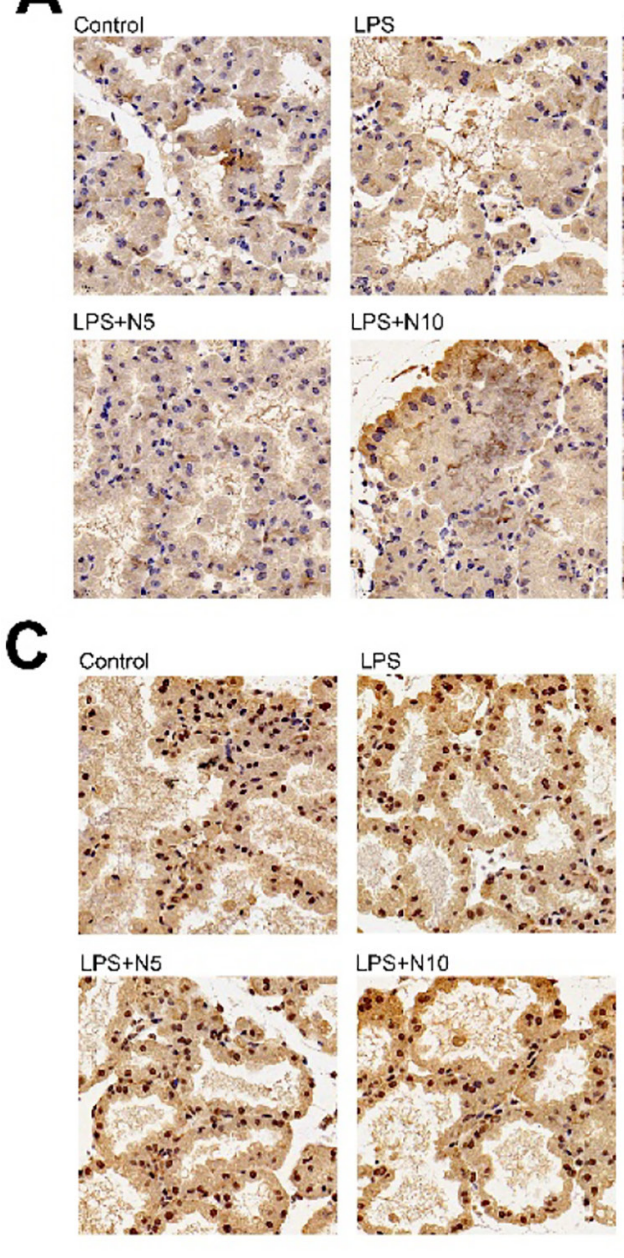

B
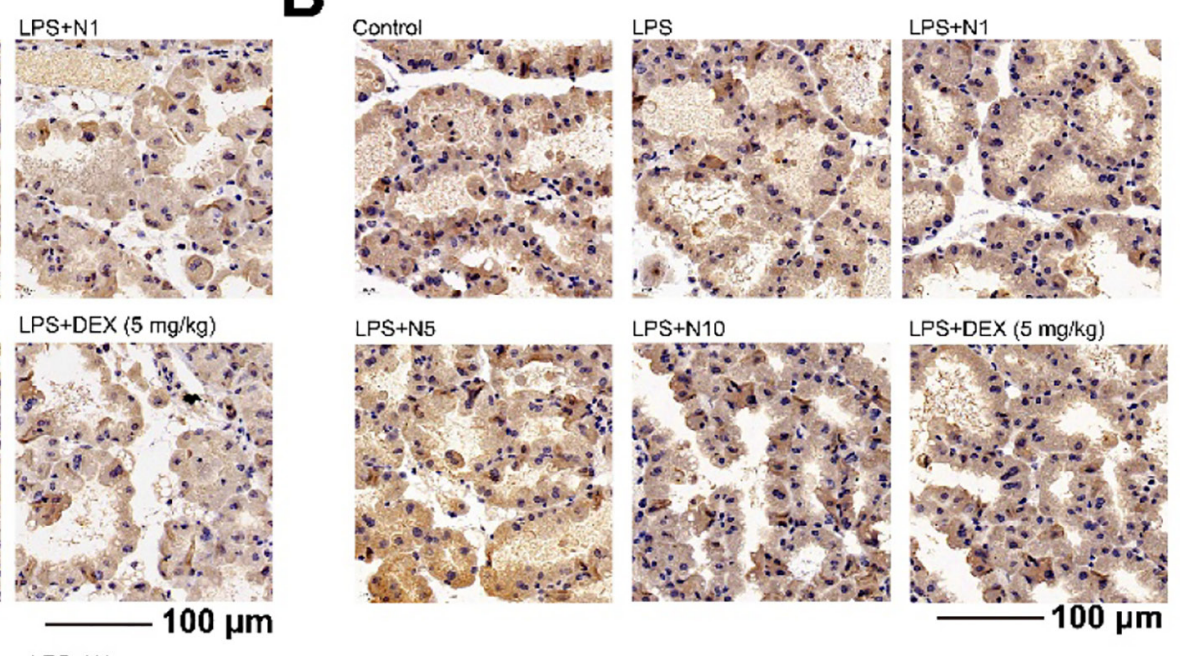

LPS $+N 10$

LPS+DEX (5 mg/kg)
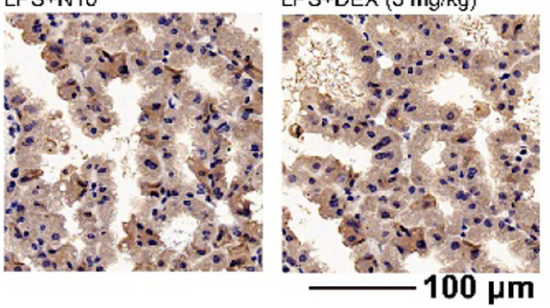

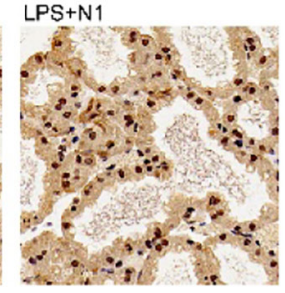

LPS+DEX $(5$ mg
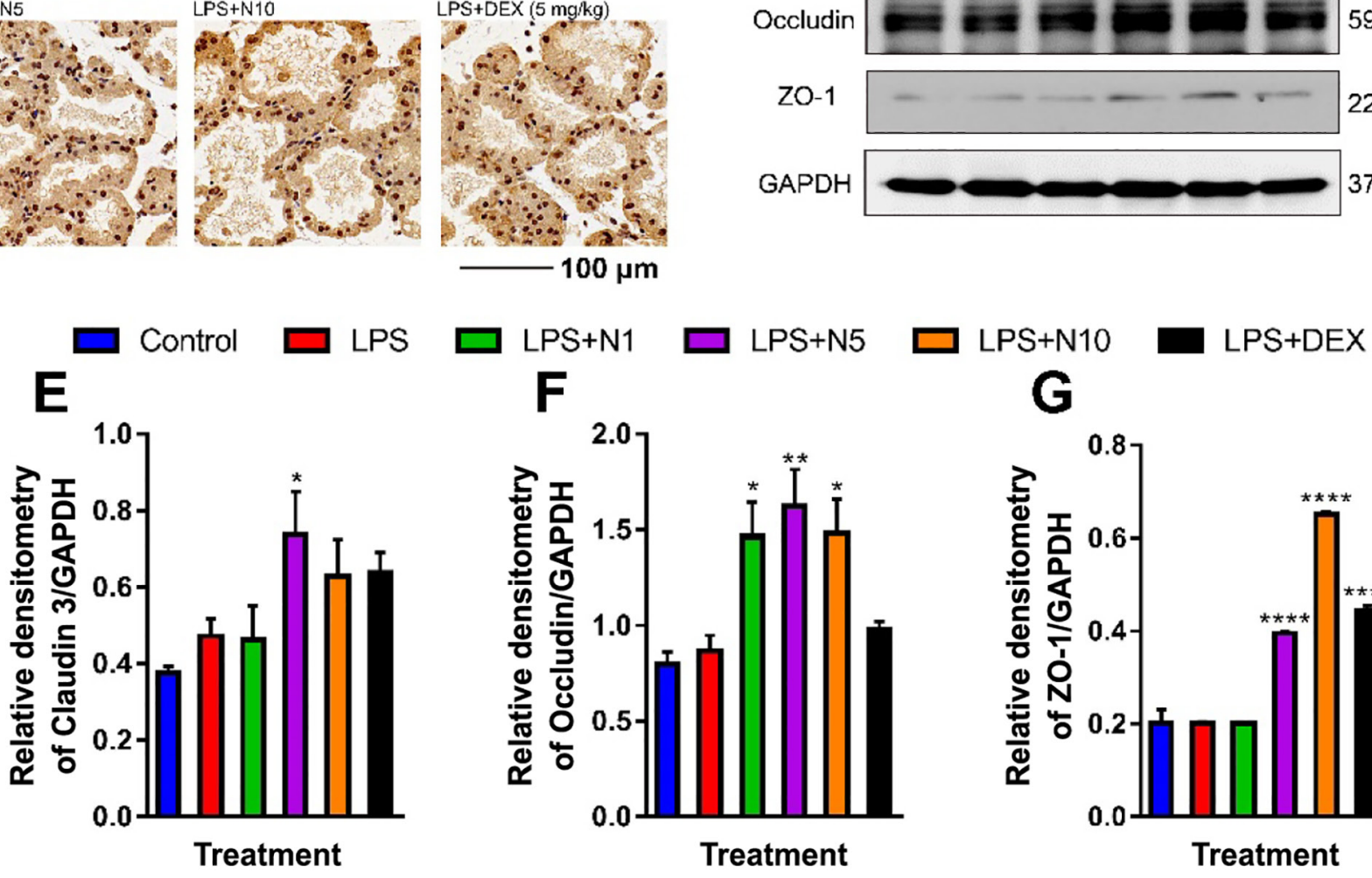

Figure 7. Effect of nisin $\mathrm{Z}$ on the integrity of the blood-milk barrier in LPS-induced mice mastitis. Immunohistochemistry for Claudin 3 (A) occludin (B), and ZO-1 (C) in mammary gland tissues of different groups of mice $(\mathrm{n}=3)$. (D) Protein bands of claudin 3, occludin, and ZO-1 in different groups. (E, F, and G) Relative densitometry of claudin 3/GAPDH, occludin/GAPDH, and ZO-1/GAPDH, respectively. Values are presented as mean \pm SEM $(\mathrm{n}=2)$. ${ }^{*} P<0.05,{ }^{*} P<0.01, * * * * P<0.0001$ versus LPS group. 
a minor extent. This might account for the noninhibition of NF- $\kappa \mathrm{B}$ by nisin Z. In addition, inflammation is a complex organismal immune response. Differences in the regulation of nisin $\mathrm{Z}$ in NF- $\kappa \mathrm{B}$ and MAPK might involve other transcriptional regulators which may be affected directly or indirectly by nisin Z. In the case of mastitis caused by $E$. coli, it has been described that more than 30 genes related to transcription factors and their regulators are activated in the mammary gland of bovines. For example, EGR1 and JUNB, are both upregulated in response to stimulation induced by E. coli and Staph. aureus (Günther et al., 2017). We supposed that nisin treatment might also affect these genes, resulting in significantly inhibited MAPK rather than NF- $\kappa$ B.

The blood-milk barrier has important physiological functions, and TJ are an essential component to ensure the integrity of the blood-lactation barrier (Mahnke et al., 2016, Tsugami et al., 2017). It has been shown that LPS reduces the integrity of the blood-milk barrier by downregulating the expression of TJ proteins, thus making it more susceptible to being infected by pathogens (Wang et al., 2017). Because mastitis involves an overactive inflammatory response and unpredictable infection by exogenous pathogens. Therefore, regulating the immune response and thus decreasing the inflammatory response, or enhancing the blood-milk barrier and thus increasing the host's resistance to infection by pathogens are important strategies to attenuate mastitis. Increasing the expression of TJ proteins can decrease the permeability of the blood-milk barrier and facilitate the improvement of mastitis (Guo et al., 2019). We found that nisin Z upregulated the expression of TJ proteins, indicating that nisin $\mathrm{Z}$ promotes the integrity of the blood-milk barrier. A similar result was also reported for myricetin $(2.5,5$, and $10 \mathrm{mg} / \mathrm{kg}$ ) that also alleviates mastitis (Kan et al., 2019).

Several reports have demonstrated the efficacy of nisin in the treatment of mastitis in cows. For example, Cao et al. (2007) reported that nisin reduced the mammary gland infections of mastitis-causing bacteria, including E. coli, Staph. aureus, and Strep. agalactiae in cows. Wu et al. (2007) also reported the therapeutic effect of nisin $\mathrm{Z}$ on subclinical mastitis in lactating cows. We further explored the mechanism about how nisin $\mathrm{Z}$ attenuates mastitis using a mouse model. We showed the inhibitory effect of nisin $\mathrm{Z}$ on mastitis and explored the potential mechanism. In summary, our study demonstrated that nisin $\mathrm{Z}$ alleviates LPSinduced inflammation by inhibiting ERK1/2 and p38 MAPK activation and reducing the release of inflammatory cytokines (IL-6, IL-1 $\beta$, and TNF- $\alpha$ ) in both MCF10A cells and mastitis mice models. Nisin Z also alleviates inflammation by enhancing the blood-milk barrier in mastitis mice. It is worth mentioning that our mechanistic results are from human cells and mice and that the transfer to bovine mechanisms needs to be made with caution.

\section{ACKNOWLEDGMENTS}

This work was supported by the National Natural Science Foundation of China (U20A2066, 31972049; Beijing, China) and the Strategic Priority Research Program of the Chinese Academy of Sciences (XDA26040201; Beijing, China). The authors have not stated any conflicts of interest.

\section{REFERENCES}

Akhtar, M., A. Shaukat, A. Zahoor, Y. Chen, Y. Wang, M. Yang, T. Umar, M. Guo, and G. Deng. 2020. Hederacoside-C inhibition of Staphylococcus aureus-induced mastitis via TLR2 \& TLR4 and their downstream signaling NF- $\mathrm{BB}$ and MAPKs pathways in vivo and in vitro. Inflammation 43:579-594. https://doi.org/10.1007/ s10753-019-01139-2.

Avila-Calderón, E. D., M. D. S. Ruiz-Palma, M. G. Aguilera-Arreola N. Velázquez-Guadarrama, E. A. Ruiz, Z. Gomez-Lunar, S. Witonsky, and A. Contreras-Rodríguez. 2021. Outer membrane vesicles of gram-negative bacteria: An outlook on biogenesis. Front. Microbiol. 12:557902. https://doi.org/10.3389/fmicb.2021.557902.

Begde, D., S. Bundale, P. Mashitha, J. Rudra, N. Nashikkar, and A. Upadhyay. 2011. Immunomodulatory efficacy of nisin-a bacterial lantibiotic peptide. J. Pept. Sci. 17:438-444. https://doi.org/10 $.1002 /$ psc. 1341 .

Broadbent, J. R., Y. C. Chou, K. Gillies, and J. K. Kondo. 1989. Nisin inhibits several gram-positive, mastitis-causing pathogens. J. Dairy Sci. 72:3342-3345. https://doi.org/10.3168/jds.S0022 -0302(89)79496-0.

Burvenich, C., V. Van Merris, J. Mehrzad, A. Diez-Fraile, and L. Duchateau. 2003. Severity of $E$. coli mastitis is mainly determined by cow factors. Vet. Res. 34:521-564. https://doi.org/10.1051/vetres: 2003023.

Cao, L. T., J. Q. Wu, F. Xie, S. H. Hu, and Y. Mo. 2007. Efficacy of nisin in treatment of clinical mastitis in lactating dairy cows. J. Dairy Sci. 90:3980-3985. https://doi.org/10.3168/jds.2007-0153.

Chen, L., H. Deng, H. Cui, J. Fang, Z. Zuo, J. Deng, Y. Li, X. Wang, and L. Zhao. 2017. Inflammatory responses and inflammationassociated diseases in organs. Oncotarget 9:7204-7218. https://doi .org/10.18632/oncotarget.23208.

Chen, X., X. Zheng, M. Zhang, H. Yin, K. Jiang, H. Wu, A. Dai, and S. Yang. 2018. Nuciferine alleviates LPS-induced mastitis in mice via suppressing the TLR4-NF- $\kappa$ B signaling pathway. Inflamm. Res. 67:903-911. https://doi.org/10.1007/s00011-018-1183-2.

Chen, Y., Y. Wang, M. Yang, and M. Y. Guo. 2019. Allicin inhibited Staphylococcus aureus-induced mastitis by reducing lipid raft stability via LxR $\alpha$ in mice. J. Agric. Food Chem. 67:10863-10870. https://doi.org/10.1021/acs.jafc.9b04378.

Chiba, H., M. Osanai, M. Murata, T. Kojima, and N. Sawada. 2008. Transmembrane proteins of tight junctions. Biochim. Biophys. Acta Biomembr. 1778:588-600. https://doi.org/10.1016/j.bbamem 2007.08.017.

Dilshara, M. G., K. T. Lee, R. G. P. T. Jayasooriya, C. H. Kang, S. R. Park, Y. H. Choi, I. W. Choi, J. W. Hyun, W. Y. Chang, Y. S. Kim, H. J. Lee, and G. Y. Kim. 2014. Downregulation of NO and PGE2 in LPS-stimulated BV2 microglial cells by trans-isoferulic acid via suppression of PI3K/Akt-dependent NF- $\mathrm{BB}$ and activa- 
tion of Nrf2-mediated HO-1. Int. Immunopharmacol. 18:203-211. https://doi.org/10.1016/j.intimp.2013.11.020.

Ge, B. J., P. Zhao, H. T. Li, R. Sang, M. Wang, H. Y. Zhou, and X. M. Zhang. 2021. Taraxacum mongolicum protects against Staphylococcus aureus-infected mastitis by exerting anti-inflammatory role via TLR2-NF- $\mathrm{B}$ /MAPKs pathways in mice. J. Ethnopharmacol. 268:113595. https://doi.org/10.1016/j.jep.2020.113595.

Gillespie, B. E., H. Moorehead, P. Lunn, H. H. Dowlen, D. L. Johnson, K. C. Lamar, M. J. Lewis, S. J. Ivey, J. W. Hallberg, S. T. Chester, and S. P. Oliver. 2002. Efficacy of extended pirlimycin hydrochloride therapy for treatment of environmental Streptococcus spp and Staphylococcus aureus intramammary infections in lactating dairy cows. Vet. Ther. 3:373-380.

Günther, J., W. Petzl, I. Bauer, S. Ponsuksili, H. Zerbe, H. J. Schuberth, R. M. Brunner, and H. M. Seyfert. 2017. Differentiating Staphylococcus aureus from Escherichia coli mastitis: S. aureus triggers unbalanced immune-dampening and host cell invasion immediately after udder infection. Sci. Rep. 7:4811. https://doi.org/ 10.1038/s41598-017-05107-4.

Guo, W., B. Liu, G. Hu, X. Kan, Y. Li, Q. Gong, D. Xu, H. Ma, Y. Cao, B. Huang, S. Fu, and J. Liu. 2019. Vanillin protects the blood-milk barrier and inhibits the inflammatory response in LPSinduced mastitis in mice. Toxicol. Appl. Pharmacol. 365:9-18. https://doi.org/10.1016/j.taap.2018.12.022.

Hernández-González, J. C., A. Martínez-Tapia, G. Lazcano-Hernández, B. E. García-Pérez, and N. S. Castrejón-Jiménez. 2021. Bacteriocins from lactic acid bacteria. A powerful alternative as antimicrobials, probiotics, and immunomodulators in veterinary medicine. Animals (Basel) 11:979. https://doi.org/10.3390/ani11040979.

Hu, G., D. Hong, T. Zhang, H. Duan, P. Wei, X. Guo, and X. Mu. 2018. Cynatratoside-C from Cynanchum atratum displays antiinflammatory effect via suppressing TLR4 mediated NF-kB and MAPK signaling pathways in LPS-induced mastitis in mice. Chem. Biol. Interact. 279:187-195. https://doi.org/10.1016/j.cbi .2017.10.017.

Ingman, W. V., D. J. Glynn, and M. R. Hutchinson. 2014. Inflammatory mediators in mastitis and lactation insufficiency. J. Mammary Gland Biol. Neoplasia 19:161-167. https://doi.org/10.1007/s10911 -014-9325-9.

Jia, Z., M. He, C. Wang, A. Chen, X. Zhang, J. Xu, H. Fu, and B. Liu. 2019. Nisin reduces uterine inflammation in rats by modulating concentrations of pro- and anti-inflammatory cytokines. Am. J. Reprod. Immunol. 81:e13096. https://doi.org/10.1111/aji.13096.

Kan, X., B. Liu, W. Guo, L. Wei, Y. Lin, Y. Guo, Q. Gong, Y. Li, D. Xu, Y. Cao, B. Huang, A. Dong, H. Ma, S. Fu, and J. Liu. 2019. Myricetin relieves LPS-induced mastitis by inhibiting inflammatory response and repairing the blood-milk barrier. J. Cell. Physiol. 234:16252-16262. https://doi.org/10.1002/jcp.28288.

Kany, S., J. T. Vollrath, and B. Relja. 2019. Cytokines in inflammatory disease. Int. J. Mol. Sci. 20:6008. https://doi.org/10.3390/ ijms20236008.

Kayitsinga, J., R. L. Schewe, G. A. Contreras, and R. J. Erskine. 2017. Antimicrobial treatment of clinical mastitis in the eastern United States: The influence of dairy farmers' mastitis management and treatment behavior and attitudes. J. Dairy Sci. 100:1388-1407. https://doi.org/10.3168/jds.2016-11708.

Khan, A. A., M. A. Alsahli, and A. H. Rahmani. 2018. Myeloperoxidase as an active disease biomarker: Recent biochemical and pathological perspectives. Med. Sci. (Basel) 6:33. https://doi.org/ 10.3390 /medsci6020033.

Khan, M. Z., A. Khan, J. Xiao, Y. Ma, J. Ma, J. Gao, and Z. Cao. 2020. Role of the JAK-STAT pathway in bovine mastitis and milk production. Animals (Basel) 10:2107. https://doi.org/10.3390/ ani10112107.

Kindrachuk, J., H. Jenssen, M. Elliott, A. Nijnik, L. MagrangeasJanot, M. Pasupuleti, L. Thorson, S. Ma, D. M. Easton, M. Bains, B. Finlay, E. J. Breukink, H. Georg-Sahl, and R. E. Hancock. 2013. Manipulation of innate immunity by a bacterial secreted peptide: Lantibiotic nisin $\mathrm{Z}$ is selectively immunomodulatory. Innate Immun. 19:315-327. https://doi.org/10.1177/1753425912461456.
Kobayashi, K., S. Oyama, A. Numata, M. M. Rahman, and H. Kumura. 2013. Lipopolysaccharide disrupts the milk-blood barrier by modulating claudins in mammary alveolar tight junctions. PLoS One 8:e62187. https://doi.org/10.1371/journal.pone.0062187.

Larsen, T., C. M. Røntved, K. L. Ingvartsen, L. Vels, and M. Bjerring. 2010. Enzyme activity and acute phase proteins in milk utilized as indicators of acute clinical E. coli LPS-induced mastitis. Animal 4:1672-1679. https://doi.org/10.1017/S1751731110000947.

Lewies, A., L. H. Du Plessis, and J. F. Wentzel. 2018. The cytotoxic, antimicrobial and anticancer properties of the antimicrobial peptide nisin $\mathrm{Z}$ alone and in combination with conventional treatments. Pages 21-42 in Cytotoxicity. IntechOpen.

Li, F., D. Liang, Z. Yang, T. Wang, W. Wang, X. Song, M. Guo, E. Zhou, D. Li, Y. Cao, and N. Zhang. 2013. Astragalin suppresses inflammatory responses via down-regulation of NF- $\kappa \mathrm{B}$ signaling pathway in lipopolysaccharide-induced mastitis in a murine model. Int. Immunopharmacol. 17:478-482. https://doi.org/10.1016/j .intimp.2013.07.010.

Li, Y., Z. Shi, I. Radauer-Preiml, A. Andosch, E. Casals, U. LuetzMeindl, M. Cobaleda, Z. Lin, M. Jaberi-Douraki, P. Italiani, J. Horejs-Hoeck, M. Himly, N. A. Monteiro-Riviere, A. Duschl, V. F. Puntes, and D. Boraschi. 2017. Bacterial endotoxin (lipopolysaccharide) binds to the surface of gold nanoparticles, interferes with biocorona formation and induces human monocyte inflammatory activation. Nanotoxicology 11:1157-1175. https://doi.org/10 $.1080 / 17435390.2017 .1401142$.

Liu, T., L. Zhang, D. Joo, and S. C. Sun. 2017. NF-kB signaling in inflammation. Signal Transduct. Target. Ther. 2:17023. https:// doi.org/10.1038/sigtrans.2017.23.

Mahnke, H., M. Ballent, S. Baumann, F. Imperiale, M. von Bergen, C. Lanusse, A. L. Lifschitz, W. Honscha, and S. Halwachs. 2016. The ABCG2 efflux transporter in the mammary gland mediates veterinary drug secretion across the blood-milk barrier into milk of dairy cows. Drug Metab. Dispos. 44:700-708. https://doi.org/ 10.1124/dmd.115.068940.

Mehmeti, I., B. Behluli, M. Mestani, A. Ademi, I. F. Nes, and D. B. Diep. 2016. Antimicrobial resistance levels amongst staphylococci isolated from clinical cases of bovine mastitis in Kosovo. J. Infect. Dev. Ctries. 10:1081-1087. https://doi.org/10.3855/jidc.7912.

Mouritzen, M. V., A. Andrea, K. Qvist, S. S. Poulsen, and H. Jenssen. 2019. Immunomodulatory potential of Nisin A with application in wound healing. Wound Repair Regen. 27:650-660. https://doi .org/10.1111/wrr. 12743 .

Munshi, A., and R. Ramesh. 2013. Mitogen-activated protein kinases and their role in radiation response. Genes Cancer 4:401-408. https://doi.org/10.1177/1947601913485414.

Salemi, S., J. Rethage, U. Wollina, B. A. Michel, R. E. Gay, S. Gay, and H. Sprott. 2003. Detection of interleukin 1beta (IL-1beta), IL-6, and tumor necrosis factor-alpha in skin of patients with fibromyalgia. J. Rheumatol. 30:146-150.

Shin, J. M., J. W. Gwak, P. Kamarajan, J. C. Fenno, A. H. Rickard, and Y. L. Kapila. 2016. Biomedical applications of nisin. J. Appl. Microbiol. 120:1449-1465. https://doi.org/10.1111/jam.13033.

Stelwagen, K., and K. Singh. 2014. The role of tight junctions in mammary gland function. J. Mammary Gland Biol. Neoplasia 19:131138. https://doi.org/10.1007/s10911-013-9309-1.

Tang, X., C. Liu, T. Li, C. Lin, Z. Hao, H. Zhang, G. Zhao, Y. Chen, A. Guo, and C. Hu. 2020. Gambogic acid alleviates inflammation and apoptosis and protects the blood-milk barrier in mastitis induced by LPS. Int. Immunopharmacol. 86:106697. https://doi .org/10.1016/j.intimp.2020.106697.

Triantafilou, M., and K. Triantafilou. 2005. The dynamics of LPS recognition: Complex orchestration of multiple receptors. J. Endotoxin Res. 11:5-11. https://doi.org/10.1179/096805105225006641.

Tsugami, Y., K. Matsunaga, T. Suzuki, T. Nishimura, and K. Kobayashi. 2017. Phytoestrogens weaken the blood-milk barrier in lactating mammary epithelial cells by affecting tight junctions and cell viability. J. Agric. Food Chem. 65:11118-11124. https://doi .org/10.1021/acs.jafc.7b04786. 
Turner, M. D., B. Nedjai, T. Hurst, and D. J. Pennington. 2014. Cytokines and chemokines: At the crossroads of cell signalling and inflammatory disease. Biochim. Biophys. Acta Mol. Cell Res. 1843:2563-2582. https://doi.org/10.1016/j.bbamcr.2014.05.014.

Wang, J., C. Guo, Z. Wei, X. He, J. Kou, E. Zhou, Z. Yang, and Y. Fu. 2016. Morin suppresses inflammatory cytokine expression by downregulation of nuclear factor- $\kappa \mathrm{B}$ and mitogen-activated protein kinase (MAPK) signaling pathways in lipopolysaccharidestimulated primary bovine mammary epithelial cells. J. Dairy Sci. 99:3016-3022. https://doi.org/10.3168/jds.2015-10330.

Wang, J. J., Z. K. Wei, X. Zhang, Y. N. Wang, Y. H. Fu, and Z. T. Yang. 2017. Butyrate protects against disruption of the blood-milk barrier and moderates inflammatory responses in a model of mastitis induced by lipopolysaccharide. Br. J. Pharmacol. 174:38113822. https://doi.org/10.1111/bph.13976.

Werner-Misof, C., J. Macuhova, V. Tancin, and R. Bruckmaier. 2007. Dose dependent changes in inflammatory parameters in the milk of dairy cows after intramammary infusion of lipopolysaccharide. Vet. Med. (Praha) 52:95-102. https://doi.org/10.17221/1870 -VETMED.

Wu, J., S. Hu, and L. Cao. 2007. Therapeutic effect of nisin Z on subclinical mastitis in lactating cows. Antimicrob. Agents Chemother. 51:3131-3135. https://doi.org/10.1128/AAC.00629-07.

Zeng, L., J. Tan, M. Xue, L. Liu, M. Wang, L. Liang, J. Deng, W. Chen, and Y. Chen. 2020. An engineering probiotic producing de- fensin-5 ameliorating dextran sodium sulfate-induced mice colitis via inhibiting NF-kB pathway. J. Transl. Med. 18:107. https://doi .org/10.1186/s12967-020-02272-5.

Zhang, C., S. Zhai, L. Wu, Y. Bai, J. Jia, Y. Zhang, B. Zhang, and B. Yan. 2015. Induction of size-dependent breakdown of bloodmilk barrier in lactating mice by TiO2 nanoparticles. PLoS One 10:e0122591. https://doi.org/10.1371/journal.pone.0122591.

Zheng, Y., G. Liu, W. Wang, Y. Wang, Z. Cao, H. Yang, and S. Li. 2021. Lactobacillus casei Zhang counteracts blood-milk barrier disruption and moderates the inflammatory response in Escherichia coli-induced mastitis. Front. Microbiol. 12:675492. https://doi .org/10.3389/fmicb.2021.675492.

\section{ORCIDS}

Fuqing Huang ๑ https://orcid.org/0000-0002-4691-484X Kunling Teng @ \ https://orcid.org/0000-0003-3213-7741 Yayong Liu ๑ https://orcid.org/0000-0003-4906-7911 Tianwei Wang ๑ https://orcid.org/0000-0002-6767-2034

Tianqi Xia (1) https://orcid.org/0000-0002-2078-2279

Fangfei Yun (๑) https://orcid.org/0000-0002-2734-0019

Jin Zhong ๑ https://orcid.org/0000-0001-8790-1327 